\title{
Macro-prudentiality and financial stability
}

\author{
Cristian Ionescu, PhD Candidate, Academy of Economic Studies, Romania
}

\begin{abstract}
Taking into consideration the fact that financial crises, as a manifestation form of the financial instability, are becoming more and more frequent, complex and severe, it is important to discuss about the macroeconomic prudentiality, in order to protect and save the economy of a country or of a region by the inherent fragility of a very developed financial system. Therefore, the paper aims to analyze the following aspects: the macro-prudential regulation (in order to a better understanding of the financial instability process), the development of the macro-prudential vision and instruments (but emphasizing the existing limits) and economic policies (in order to implement an operational macro-prudential regulation).
\end{abstract}

\section{Keywords:}

financial stability, financial crisis, macro-prudential regulation, macro-prudential instruments

\section{JEL Codes: E32, E44, E52, E61, G01, G21}

\section{Introduction}

The economic reality has shown that macroeconomic stability is not sufficient to acquire financial stability. For example, prior to the crisis, there may be some hidden financial imbalances in the advanced economies, despite stable growth and low inflation. Moreover, micro-prudential regulation and supervision, which focus on ensuring safety and soundness of individual financial institutions, may be inadequate because it may not contain the systemwide risks. Therefore, it was implemented a macro-prudential supervision in several emerging market economies, in order to safeguard the financial stability.

Macro-prudential measures are regulatory policies that have the objective of reducing the systemic risks, to ensure stability of the financial system as whole against internal and external shocks, and ensure that it continues to function efficiently.

\section{The need for macro-prudential regulation - developments in the understanding of the process of financial instability}

The world economy revealed an instable economic and financial background in the last 30 years: there is a growing of the generic nature of financial crises. Although the financial crises (the most severe form of financial instability) are not random, but are different, they have some common features (table 1). 
Table 1. Financial crisis- phases, nature and features

\begin{tabular}{|l|l|l|}
\hline Phase of crisis & Nature & Example of features \\
\hline $\begin{array}{l}\text { Primary } \\
\text { (favorable) shock }\end{array}$ & Diverse & $\begin{array}{l}\text { Deregulation, monetary or fiscal easing, invention, } \\
\text { change in market sentiment }\end{array}$ \\
\hline $\begin{array}{l}\text { Propagation - } \\
\text { build-up of } \\
\text { vulnerability }\end{array}$ & $\begin{array}{l}\text { Common - main } \\
\text { subject of } \\
\text { macro-prudential } \\
\text { surveillance }\end{array}$ & $\begin{array}{l}\text { New entry to financial markets, debt accumulation, } \\
\text { asset price booms, innovation in financial markets, } \\
\text { under-pricing of risk, risk concentration and lower } \\
\text { capital adequacy for banks, unsustainable macro } \\
\text { policy }\end{array}$ \\
\hline $\begin{array}{l}\text { Secondary } \\
\text { (adverse) shock }\end{array}$ & Diverse & $\begin{array}{l}\text { Monetary, fiscal or regulatory tightening, } \\
\text { asymmetric trade shock }\end{array}$ \\
\hline $\begin{array}{l}\text { Propagation - } \\
\text { crisis }\end{array}$ & $\begin{array}{l}\text { Failure of institution or market leading to failure of } \\
\text { others via direct links or uncertainty in presence of } \\
\text { asymmetric information - or generalized failure } \\
\text { due to common shock }\end{array}$ \\
\hline Policy action & $\begin{array}{l}\text { Common - main } \\
\text { subject of crisis } \\
\text { resolution }\end{array}$ & $\begin{array}{l}\text { Deposit insurance, lender of last resort, general } \\
\text { monetary easing }\end{array}$ \\
\hline $\begin{array}{l}\text { Economic } \\
\text { consequences }\end{array}$ & $\begin{array}{l}\text { Common - scope } \\
\text { severity and } \\
\text { policy action }\end{array}$ & $\begin{array}{l}\text { Credit rationing and wider uncertainty leading to } \\
\text { fall in gross domestic product, notably investment }\end{array}$ \\
\hline
\end{tabular}

(Source: Davis P.; Karim D. (2009), Macro-prudential regulation - the missing policy pillar, paper presented at the 6th Euro-frame Conference on Economic Policy Issues in the European Union)

There are both exogenous and endogenous aspects. The financial instability starts with a primary shock to the economy and financial system that is favorable to growth and investment. But the process of propagation increases the vulnerability of the economy and financial system (which involves the over-extension of balance sheets and the creation of the financial imbalances). Balance sheets grow, short term funding increases, leverage falls and mispricing arises. These amplifies the boom and leads to a crisis where a secondary (adverse) shock affects the financial system. There is further propagation in a crisis period (systemic risk) that involves high negative economic consequences (the "costs of instability”).

\section{Progress of the macro-prudential pillar - the development of macro- prudential oversight}

\subsection{Tools for macro-prudential analysis}

"Distance to Default" measures the credit risk by expressing a firm's net worth as a ratio of asset price volatility; the higher the ratio, the lower the probability of default. Any asset traded on a liquid secondary market can be used in calculating the "distance to default", because taking into account the assumption of market efficiency, prices will incorporate markets' forward looking expectations of firm default. But when "distance to default" is computed for the banking sector, it ignores the possibility of regulators intervening properly before default. Banking "distance to default" measures reflects the Basel regulatory capital requirements.

Stress tests quantify portfolio movements for unlikely but feasible events. Scenario tests simultaneously modify several risks in one direction, emulating historic events or hypothetical scenarios. But limitations arise because probabilities of shocks materializing are 
not calculated. Also, risk parameters are subjectively chosen by managers and impose high computational costs on institutions ${ }^{1}$.

Bubble detection searches for bubble premiums, excess volatility and co-integration between dividends and prices.

Early Warning Systems generate crisis probabilities using empirical historic data (macroeconomic, financial and structural indicators). Early Warning Systems follows individual time series for previous anomalous associated-with-crises behavior. If an indicator has an anomalously behavior, there can be calculated a crisis probability. Some signal extractions for banking crisis prediction are improved by creating composite indicators weighted by their signaling quality.

The binary recursive tree technique is used to analyze which non-linear variable interactions make an economy more vulnerable to crisis than others ${ }^{2}$. Liquidity, credit and market risks are potentially nonlinear. The binary recursive tree identifies the most important discriminator between crisis and non-crisis episodes, and creates two nodes which are split into sub-nodes, depending on the behavior of splitter variables' non-linear interactions with previous splitter variables. This may help in calculating the nodal crisis probabilities.

\subsection{The limits of macro-prudential oversight}

The financial crisis may be only partially foreseen; thus, the regulators may not observe some key feature of the crisis or may not foresee the collapse of the interbank market or the overall magnitude of the effects of a financial crisis. It is also possible that some crucial links from financial instability to the real economy could not be easily observed. Therefore, a proper forward looking analysis of events and possible policy responses are essential regarding the longer term concern over the build-up of debt, risks and rising asset prices.

The macro-prudential tools are limited. The global early warning systems, although quite performing, were not completely capable of predicting some of the financial crises (although some models had a very high crisis prediction score).

It may be possible that financial crises have specific characteristics that are not typical of the common banking crises in both advanced and emerging economies. Therefore, it is important to adapt the existing models, adding the specific characteristics of advanced economies. This would improve the macro-prudential analysis.

\section{Policy issues - an operational macro-prudential regulation}

\subsection{The broad issue}

The initial policy objectives of macro-prudential regulation were: a) the early identification of potential vulnerabilities and b) through the public reporting, the encouragement of financial institutions to do stress testing ${ }^{3}$. There is now a third objective: the encouragement of preventative and remedial policies to prevent financial instability. In the worst case scenario, surveillance should resolve instabilities when preventative and remedial measures fail. But some of the preventative measures (moral suasion and intensified supervision) are not sufficient. Therefore, it is important to know if monetary policy can manage asset price bubbles (some central banks consider that monetary policy shouldn't deflate bubbles, because of the interest rate instrument which is meant to control inflation.

But the economic and financial reality suggests there is a need for variation or adjustment in prudential parameters.

\footnotetext{
${ }^{1}$ Davis P.; Karim D. (2009), Macro-prudential regulation - the missing policy pillar, The 6th Euro-frame Conference on Economic Policy Issues in the European Union

2 idem

${ }^{3}$ Barua R.; Battaglia F.; Jagannathan R.; Mendis J.; Onorato M. (2010), Basel III: What's New? Business and Technological Challenges
} 
The entire rationale of macro-prudential regulation is that relying on individual bank supervision at a micro level is not sufficient. Therefore, one important issue is the manner that should be used in order to link macro-prudential and micro-prudential regulation more effectively. One solution is to design a proper countercyclical regulatory framework (the time series dimension), which includes increasing risk weights for risks that are common across institutions rather than idiosyncratic (the cross section dimension). It is essential that macro-prudential regulation and micro-prudential regulation become more effective in ensuring that risky activities do not move internationally or to weak-regulated financial institutions.

\subsection{Cross sectional regulation}

One aspect of macro-prudential regulation is the allowance of cross sectional risks. But not all institutions involve similar systemic risks (these may be large and/or highly connected with other institutions). Developing models to measure such systemic importance is a key ongoing task. Regulation may impose a tighter regulation and higher capital requirements on systemically important institutions.

There may be necessary to impose higher capital charges on behavior that is typically common across banks relative to that which is idiosyncratic, even if the risks to the individual institutions are the same. Because banks may involve a "herding" behavior and because there may be a high correlation of balance sheet risk, there should be implemented more severe controls on lending to finance real estate (an important market that often leads to collective losses as asset prices fall). These may involve limits to loan to value ratios, changing the bank reliance on wholesale funds, raising capital requirements for banks etc. Macro-prudential problems are threefold: a) bad lending (which determine losses that involve liquidity problems), b) excessive reliance on wholesale markets and c) complex instruments leading to confusion ${ }^{4}$. Because there is an "uncertainty" problem regarding the lack of experience of behavior in downturns, the regulation of complex instruments, an increase in capital held against them, higher capital charges and even the need to justify innovations before introducing are essential, especially if it is taken into consideration the severe damages induced by the majority of asset backed security innovations.

\subsection{Changes in the structure of regulation}

The regulation boundary problem involve that effective regulation do not lead to substitution flows towards the unregulated sector. Moreover, it is necessary for the regulators to ensure that banks do not move subsidiaries outside the regulatory net.

One motive of the severity of the last financial crises was the decision in the 1980s and 1990s to move away from structural regulation (limits on competition, prices and scope of activities for financial institutions) to the concern regarding the efficiency of the financial system. Of course, both of them should be taken into consideration by regulators, and the costs and benefits of both should be balanced. Efficient financial markets increase welfare, reduce risk premium and raise sustainable output ${ }^{5}$. They tend to produce financial products that are widely adopted and used before they are stress tested in a recession. Therefore, the prudential tightening and the direct controls on bank activities are essential in assuring the financial units health and stability, which finally induces overall financial stability.

Another important issue is the development of macro-prudential regulation between the central bank and regulator (if they are separate) or within the central bank. Regulators outside the central bank are less focused on macro-prudential issues than the central bank. One explanation for this is the higher focus on depositor and investor protection, which leads

\footnotetext{
${ }^{4}$ idem

${ }^{5}$ ibidem
} 
to a concentration on individual institutions. Another explanation is that the central bank will have to manage the initial consequences of systemic risk (using the lender of last resort instrument). Therefore, it may be necessary to rebalance the responsibilities between institutions in order to ensure a proper macro-prudential framework.

\section{The use of macro-prudential instruments 5.1. Macro-prudential instruments}

The financial crises have shown that not even a perfect conformity with the best practices regarding financial supervision and regulation can ensure macro-financial stability. The lack of a proper analytical framework and the gaps in policy tools have reborn the interest in macro-prudential policies. Macro-prudential policy and macro-prudential instruments are the set of measures that aim to monitor, prevent, and address system-wide risks, and minimize the cost of systemic crises ${ }^{6}$. In order for a macro-prudential policy to be effective, a coherent institutional framework for effective surveillance and policy design and implementation is needed.

Regarding the macro-prudential instruments, there is no standard taxonomy. The time-series dimension of financial stability is different from the cross-sectional dimension.

Therefore, macro-prudential tools are twofold: a) the tools that reduce the pro-cyclicality of the financial system (countercyclical capital and provisioning requirements, maximum loanto-value ratios and reductions in securities financing and derivative transactions) and b) the tools that reduce the risk of the common exposures that arise owing to balance sheet interlinkages (net stable funding ratio, limits for maturity mismatches).

Another macro-prudential tools classification is based on whether they are rule-based (automatic stabilizers) or discretionary; or whether they introduce quantity restrictions or price restrictions ${ }^{7}$. The Bank of International Settlements uses a classification linking macroprudential measures with micro-prudential categories (table 2). This is a pragmatic approach, as macro-prudential measures reduce risks at the microeconomic level and because some of the micro-prudential measures are macro-prudential instruments when aiming to address systemic risks.

\subsection{Developments and types of macro-prudential instruments}

A macro-prudential instrument is any macro-prudential or micro-prudential measure that is used to address systemic risk. In the category of macro-prudential measures will enter only regulations.

Table 2: Macro-prudential instruments

\begin{tabular}{|c|c|}
\hline $\begin{array}{l}\text { Risk } \\
\text { measurement } \\
\text { methodologies }\end{array}$ & \\
\hline $\begin{array}{l}\text { By banks } \\
\text { By supervisors }\end{array}$ & $\begin{array}{l}\text { Risk measures calibrated through the cycle. } \\
\text { Cyclical conditionality in supervisory ratings of firms; develop } \\
\text { measures of systemic vulnerability (e.g. commonality of exposures and } \\
\text { risk profiles, intensity of inter-firm linkages) as basis for calibration of } \\
\text { prudential tools; communication of official assessments of systemic } \\
\text { vulnerability and outcomes of macro stress tests. }\end{array}$ \\
\hline
\end{tabular}

\footnotetext{
${ }^{6}$ Delgado F.; Meza M. (2011), Developments in Financial Supervision and the Use of Macro-prudential Measures in Central America, International Monetary Fund

${ }^{7}$ idem
} 


\begin{tabular}{|c|c|}
\hline $\begin{array}{l}\text { Financial } \\
\text { reporting } \\
\text { Accounting } \\
\text { standards } \\
\text { Prudential filters }\end{array}$ & $\begin{array}{l}\text { Adjust accounting figures as a basis for calibration of prudential tools; } \\
\text { Use of less pro-cyclical accounting standards; dynamic provisions. } \\
\text { Prudential provisions as add-on to capital; smoothing via moving } \\
\text { averages of such measures; time-varying target for provisions or for } \\
\text { maximum provision rate. } \\
\text { Disclosures of various types of risk (e.g. credit, liquidity), and of } \\
\text { uncertainty about risk estimates and valuations in financial reports or } \\
\text { disclosures. }\end{array}$ \\
\hline $\begin{array}{l}\text { Regulatory } \\
\text { capital } \\
\text { Pillar } 1\end{array}$ & $\begin{array}{l}\text { Systemic capital surcharge; reduce sensitivity of regulatory capital } \\
\text { requirements to current point in the cycle and with respect to } \\
\text { movements in measured risk; introduce cycle-dependent multiplier to } \\
\text { the point-in-time capital figure; increased regulatory capital } \\
\text { requirements for particular exposure types (higher risk weights than } \\
\text { on the basis of Basel II, for macro-prudential reasons). } \\
\text { Link of supervisory review to state of the cycle. }\end{array}$ \\
\hline $\begin{array}{l}\text { Funding } \\
\text { liquidity } \\
\text { standards }\end{array}$ & $\begin{array}{l}\text { Cyclically-dependent funding liquidity requirements; concentration } \\
\text { limits; foreign exchange lending restrictions; foreign exchange reserve } \\
\text { requirements; currency mismatch limits; open foreign exchange position } \\
\text { limits. }\end{array}$ \\
\hline $\begin{array}{l}\text { Collateral } \\
\text { arrangements }\end{array}$ & $\begin{array}{l}\text { Time-varying Loan-to-value ratios; conservative maximum loan-to- } \\
\text { value ratios and valuation methodologies for collateral; limit extension } \\
\text { of credit based on increases in asset values }\end{array}$ \\
\hline $\begin{array}{l}\text { Risk } \\
\text { concentration } \\
\text { limits }\end{array}$ & $\begin{array}{l}\text { Quantitative limits to growth of individual types of exposures; (time- } \\
\text { varying) interest rate surcharges to particular types of loans. }\end{array}$ \\
\hline $\begin{array}{l}\text { Compensation } \\
\text { schemes }\end{array}$ & $\begin{array}{l}\text { Guidelines linking performance-related pay to ex ante longer-horizon } \\
\text { measures of risk; use of supervisory review process for enforcement. }\end{array}$ \\
\hline $\begin{array}{l}\text { Profit } \\
\text { distribution } \\
\text { restrictions }\end{array}$ & $\begin{array}{l}\text { Limit dividend payments in good times to help build up capital buffers } \\
\text { in bad times. }\end{array}$ \\
\hline $\begin{array}{l}\text { Insurance } \\
\text { mechanisms }\end{array}$ & $\begin{array}{l}\text { Contingent capital infusions; pre-funded systemic risk insurance } \\
\text { schemes; pre-funded deposit insurance with premium sensitive to macro } \\
\text { (systemic risk) in addition to micro (institution specific) parameters. }\end{array}$ \\
\hline $\begin{array}{l}\text { Managing } \\
\text { failure } \\
\text { resolution }\end{array}$ & $\begin{array}{l}\text { Exit management policy conditional on systemic strength; trigger points } \\
\text { for supervisory intervention stricter in booms than in periods of } \\
\text { systemic distress }\end{array}$ \\
\hline
\end{tabular}

Regarding classification, the instruments can be divided into six categories: 1) traditional measures; 2) sectoral measures; 3) maturity mismatches; 4) credit growth limits; 5) foreign exchange risk and capital inflows; and 6) countercyclical measures (table 3).

Table 3. Classification of macro-prudential tools

\begin{tabular}{|l|l|}
\hline Type of measure & Measure \\
\hline $\begin{array}{l}\text { Traditional macro and } \\
\text { micro-prudential measures }\end{array}$ & Maximum limit on loan to value ratios \\
& $\begin{array}{l}\text { Debt to income ratio } \\
\text { Reserve requirements }\end{array}$ \\
\hline
\end{tabular}




\begin{tabular}{|l|l|}
\hline $\begin{array}{l}\text { Sectoral and other specific } \\
\text { measures }\end{array}$ & $\begin{array}{l}\text { Limits on credit concentrations with respect to specific sectors } \\
\text { Mandatory provisions on exposures to specific sectors }\end{array}$ \\
\hline Maturity mismatches & $\begin{array}{l}\text { Limits on maturity mismatches on bank balance sheets } \\
\text { Limits on net non-core funding dependence ratio } \\
\text { Minimum core funding ratio }\end{array}$ \\
\hline Limit credit growth & $\begin{array}{l}\text { Credit ceilings } \\
\text { Loan-to-deposit limits }\end{array}$ \\
\hline $\begin{array}{l}\text { Foreign exchange risk and } \\
\text { capital }\end{array}$ & $\begin{array}{l}\text { Limits on open foreign exchange } \\
\text { Specific capital requirements for net open foreign exchange } \\
\text { Reserve requirements on external credit lines to banks } \\
\text { Specific capital requirements for foreign exchange lending } \\
\text { Limits to foreign investment by domestic pension funds } \\
\text { Tax on capital inflows }\end{array}$ \\
\hline $\begin{array}{l}\text { New } \\
\text { measures }\end{array}$ & $\begin{array}{l}\text { Dynamic (cyclically based) loan loss provisioning rules } \\
\text { Cyclically based capital adequacy ratios }\end{array}$ \\
(Source: Delgado F.; Meza M. (2011), Developments in Financial Supervision and the Use of Macro-prudential \\
Measures in Central America, International Monetary Fund)
\end{tabular}

\section{References:}

1. Barua R.; Battaglia F.; Jagannathan R.; Mendis J.; Onorato M. (2010), Basel III: What's New? Business and Technological Challenges

2. Basel Committee on Banking Supervision (2011), Marrying the macro and micro-prudential dimensions of financial stability, Bank for International Settlements

3. Basel Committee on Banking Supervision (2010), The Basel Committee's response to the financial crisis: report to the G20, Bank for International Settlements

4. Basel Committee on Banking Supervision (2010), Basel III: International framework for liquidity risk measurement, standards and monitoring, Bank for International Settlements

5. Basel Committee on Banking Supervision (2011), Progress report on Basel III implementation, Bank for International Settlements

6. Basel Committee on Banking Supervision (2010), Basel III: A global regulatory framework for more resilient banks and banking systems, Bank for International Settlements

7. Davis P.; Karim D. (2009), Macro-prudential regulation - the missing policy pillar, paper presented at the 6th Euro-frame Conference on Economic Policy Issues in the European Union

8. Delgado F.; Meza M. (2011), Developments in Financial Supervision and the Use of Macroprudential Measures in Central America, International Monetary Fund

9. Elliott D. (2010), Basel III, the Banks, and the Economy, The Brookings Institution

10. Galati, G.; Moessner R. (2011), Macro-prudential Policy - A Literature Review. Bank of International Settlements

11. Resti A. (2002), The new Basel capital accord structure, possible changes and micro-and macroeconomic effects, Centre for European Policy Studies

12. Resti A. (2004), The new Basel capital accord and the future of the European financial system rapporteurs, Centre for European Policy Studies

13. Unsal F. (2011), Capital Flows and Financial Stability: Monetary Policy and Macro-prudential Responses, International Monetary Fund

14. Woolford I. (2011), Implementation of Basel III capital adequacy requirements in New Zealand, Reserve Bank of New Zealand 